\title{
Subacute and rehabilitation care facilities " Soins de Suite et de Réadaptation (SSR) », dedicated to HIV patients in Marseilles, France
}

Jean-Paul Dimet, Gabrielle Vinai, Berengère Labarrière, Loïc Julien, Eliane Lerda, Nadia Timezouaght, Nathalie Petit

From $16^{\text {th }}$ International Symposium on HIV and Emerging Infectious Diseases

Marseille, France. 24-26 March 2010

\section{Background}

To describe sociodemographic and clinical characteristics of HIV inpatients of Polyclinique La Feuilleraie in Marseilles. Five beds of SSR are dedicated to HIV people in this clinic.

\section{Methods}

Local database from January 2003 to June 2009.

\section{Results}

Admission criteria were wide, including patients ongoing opioid substitution treatment or still intravenous drug users. Patients were mostly transfered from acute medical care units in Marseilles geographic area (88\%). Therapeutic objectives vary from monitoring somatic recovery, monitoring newly prescribed HAARTand VHC therapy, seeking for supportive housing, palliative care...

There were few patients who had long and repeated stays in the unit (103 pts with 199 stays). Length of stay exceeded 31 days for $42 \%$ of the patients. Most of them have low socioeconomic status (63\% COTOREPAAH,31\% CMU,7\% RMI). Disability profile was rather severe - measured by impairment in activities of daily living, ADL, and instrumental activities of daily living, IADL - with one third of patients with $A D L<3$ and mean IADL score of 2 .

Immune status was low, with $49 \%$ of the patients who had less than $200 \mathrm{CD} 4 / \mathrm{mul}$ and $42 \%<500 \mathrm{CD} 4 / \mathrm{mul}$. $56 \%$ had AIDS and 60\% were co-infected by VHC virus. $40 \%$ of patients had psychotropic medications on admission. Discharge destination was not adequate for $21 \%$ of

\footnotetext{
* Correspondence: docteur.olipet@wanadoo.fr
}

Polyclinique La Feuilleraie, Marseille, France the patients (patients with neurocognitive disorders, and/or psychiatric disorders and/or housing problems, who needed housing in special structures). Therapeutic objectives were not reached in one third of the stays.

\section{Discussion}

SSR dedicated to HIV inpatients in Marseilles remains a pilot experience in the region. Patients have growing inadequate discharge orientation, and growing lengths of stays, which are not compatible with the definition of SSR. New payment-by-the-act funding system should consider the specificity of HIV care in SSR.

Published: 11 May 2010

doi:10.1186/1742-4690-7-S1-P110

Cite this article as: Dimet et al: Subacute and rehabilitation care

facilities "Soins de Suite et de Réadaptation (SSR) ", dedicated to HIV patients in Marseilles, France. Retrovirology 2010 7(Suppl 1):P110.

Submit your next manuscript to BioMed Central and take full advantage of:

- Convenient online submission

- Thorough peer review

- No space constraints or color figure charges

- Immediate publication on acceptance

- Inclusion in PubMed, CAS, Scopus and Google Scholar

- Research which is freely available for redistribution

Submit your manuscript at www.biomedcentral.com/submit
Biomed Central 